\title{
Balancing growth, profitability and safety in the German insurance market*
}

\author{
Liselotte Maichel-Guggemoos and Joël Wagner ${ }^{\ddagger}$
}

\begin{abstract}
The contribution of this paper is to provide an improved understanding of the relationship between the three strategic objectives growth, profitability and safety of insurance companies in Germany. Extending on the work by Eling et al. (2017), we introduce measures and provide descriptive statistics for each objective. Our numerical analysis relies on panel data of German insurers for the years from 2001 to 2016 providing almost full market coverage. We apply different statistical tests and multilinear regression models to test how and to what extent the objectives are related. At the same time, we control for the legal status, the size of the insurance business and the calendar year. Regarding the total insurance market, our results suggest a positive and significant relationship between growth and profitability and a negative significant one between the safety level and profitability. Further, mutual and public insurers relate to lower growth and higher safety levels than listed companies. For the business volume, we find that larger companies tend to grow at a lower rate when compared to smaller companies while achieving higher profitability but lower safety levels. The results per business line show that life insurers yield significantly different results from non-life insurers. Thus, we separately analyze and discuss the results for the life and the non-life sectors.
\end{abstract}

Key words: German insurance market · strategic objectives · growth - profitability - safety - empirical analysis

\footnotetext{
${ }^{*}$ This is a post-peer-review, pre-copyedit version of an article published in Zeitschrift für die gesamte Versicherungswissenschaft. The final authenticated version is available online at: https://doi.org/10.1007/s12297-019-00439-8.

${ }^{\dagger}$ This work summarizes the main findings of research presented by the authors at the annual meeting of "Deutscher Verein für Versicherungswissenschaft e. V." in Berlin, March 2019.

${ }^{\ddagger}$ Liselotte Maichel-Guggemoos (liselotte.maichel@unil.ch) and Joël Wagner (joel.wagner@unil.ch) are with the Department of Actuarial Science, Faculty of Business and Economics, University of Lausanne. The second author is also with the Swiss Finance Institute, University of Lausanne, Switzerland.
} 


\section{Introduction}

The German insurance market is a mature market. Over the last 20 years, the insurance penetration measured in terms of the total premiums as a percentage of the gross domestic product (GDP) remains roughly at the same level with $6.5 \%$ in 1996, 6.7\% in 2006 and $6.1 \%$ in 2016 (Swiss Re Institute, 1998, 2007, 2017). The maturity of the German market is also illustrated by the "S-curve" analysis of the Swiss Re Institute (2015). The majority of the European countries with high income levels, including Germany, are situated on the flat section of the curve, where we find the saturated markets. In this part of the "S-curve", premiums typically grow at about the same level as the GDP per capita (adjusted for inflation). This entails that a company in a mature market can only grow above average, i.e., compared to its competitors, if it can convince customers to transfer from other insurance providers or if it makes previously uninsured persons buy insurance. In the case of a growing insurance portfolio several questions have to be analyzed regarding the quality of growth. In fact, the quality of growth is clearly linked to profitability and safety. Regarding the profitability of German insurance companies, the ongoing low interest rate environment since 2008 has increased the pressure on profitability, especially for life insurance companies. Firms are obliged to fulfill high interest rate guarantees promised in the past (Demary and Matthes, 2014) with guaranteed rates averaging, e.g., $3.1 \%$ in 2013 (GDV, 2014, 2016). The Federal Ministry of Finance has lowered the maximum technical interest rate from 2000 onward from $4 \%$ to $0.9 \%$ in 2017. One possible approach for insurers to decrease the average guaranteed interest rate in their books is to focus on growth. With the inflow of new business with lower or without any guaranteed interest rates, an insurance company can decrease the average rate in the portfolio. Looking at the total return, insurers need to consider both sides of the balance sheet, liabilities as well as assets. The composition of the capital investments of life insurers in Germany has changed in recent years from a focus on bonds and mortgages to more variable yield securities (Maichel-Guggemoos and Wagner, 2019). In non-life insurance, the profitability is influenced by phases of high competition in some product lines, e.g. motor insurance. This business has experienced phases of low-price levels, e.g. from 1996 to 1999 and from 2005 to 2006. In such market environment, companies have tried to underprice one another to achieve grow. This has come with negative effects on their profitability. When looking at the profitability of German insurers questions regarding growth rates and prevailing safety levels are to be considered.

With our paper we aim to contribute to an improved understanding of the relationship between growth, profitability and safety in German insurance companies. For our analysis we define key indicators for the three strategic objectives. We apply different statistical tests and multilinear regression models to test how and to what extend the objectives are related. Thereby, we control for other parameters like the legal status of the company, the size of the business and the calendar year. We provide an analysis of the total market before analyzing the life and non-life insurance sectors. Our work extends existing literature and is closest to the analysis of global insurance markets with an international perspective by Eling et al. (2017). They analyze a sample of European insurance companies over 11 years, testing various hypotheses on the interdependencies of growth, profitability and safety. For further literature, we refer to the references given by Eling et al. (2017). Further, in their study on European growth champions in insurance, Schwarz et al. (2008) analyze a sample of 279 European life insurance companies from 2002 through 2005 regarding growth and profitability. They find that larger life insurers, in terms of GWP, tend to grow faster than smaller ones. However, the size does not have a 
significant impact on the profitability of life insurers when measured by the technical margin.

The paper is organized as follows: Section 2 introduces the research topic and provides an overview of the key indicators used to describe growth, profitability and safety (Section 2.1), descriptive statistics (Section 2.2) and information on the panel data (Section 2.3). Section 3 presents the model framework (Section 3.1) and discusses the results for the total market as well as separately for the life and non-life markets (Section 3.2). Our main findings and potential areas of future research are summarized in Section 4. The Appendix provides the list of insurance groups included in our analysis.

\section{Growth, profitability and safety}

This section introduces three key strategic management objectives of an insurance company, namely growth, profitability and safety. Eling et al. (2017) provides an extensive literature review on these goals in the insurance industry. We define key indicators suited to represent and to size these objectives. Then, we provide descriptive statistics to show the historical development in Germany. First, we choose indicators that can be used for both sectors, i.e., life and non-life, to allow for a holistic picture. In addition, we define more specific indicators tailored for either the life or the non-life sector to enable more specific analyses. All indicators are calculated on the group level and not on the single entity level to avoid "artificial" growth rates due to internal mergers.

\subsection{Indicators}

\section{Growth indicators}

For growth indicators we consider the year-on-year percentage growth rates of gross written premiums (GWP) for the total market and both sectors, of the number of contracts for the non-life sector and of the volume of capital investments for the life sector.

Premium growth (PG). Measuring growth in terms of gross written premiums is widespread in the insurance literature. For example, Swiss Re uses it in their yearly publication to quantify the insurance developments worldwide (Swiss Re Institute, 2017). It is also used in the academic literature, see, e.g., Cole et al. (2015). In the definitions below, the time $t$ corresponds to the financial year, $i$ stands for the insurer and sector $s$ can take the values life, non-life and total. We only include the sector $s$ when an indicator is applied to more than one sector; conversely, when an indicator is specific to one sector we omit the superscript $s$. We define premium growth as follows:

$$
P G_{i, t}^{s}=\frac{\mathrm{GWP}_{i, t}^{s}-\mathrm{GWP}_{i, t-1}^{s}}{\mathrm{GWP}_{i, t-1}^{s}}
$$

Contract growth (CG). Since premium levels for insurance products follow cycles, premium variation may introduce bias in the growth measurements. Thus, we also include the growth rate of the number of insurance contracts. This is especially important in non-life insurance. One of the reasons is, for example, the dominance of the motor insurance business in Germany accounting for, on average, $39 \%$ of the non-life GWP in the last 15 years. The motor insurance industry has experienced phases of hard price competition and therefore changing premium 
levels (Eling and Luhnen, 2008; Maichel-Guggemoos and Wagner, 2018). Contract growth is given by:

$$
C G_{i, t}=\frac{\operatorname{contracts}_{i, t}-\operatorname{contracts}_{i, t-1}}{\operatorname{contracts}_{i, t-1}}
$$

Investment growth $(I G)$. For life insurance companies we consider the growth rate of the capital investments as an additional indicator. Describing life insurance companies according to the volume of the capital investments is, e.g., also done by De Haan and Kakes (2011) in their analysis of investment strategies. In addition, Gal et al. (2016) use this measure in their publication on the role of life insurance companies as institutional investors. We include capital investments from German life insurance companies (excluding pension funds), measured as end-of-year book values according to German GAAP (BaFin, 2015). We define investment growth as follows:

$$
I G_{i, t}=\frac{\text { investments }_{i, t}-\text { investments }_{i, t-1}}{\text { investments }_{i, t-1}}
$$

\section{Profitability indicators}

For profitability indicators, we consider the return on equity for the total market as well as separately for the non-life sector. In addition, profitability is measured by the return on assets and the technical margin for the life sector and by the loss ratio for the non-life sector.

Return on equity (ROE) and return on assets (ROA). Both indicators are frequently used in the literature to measure the performance of an insurance company. In their work on strategic group performance, Altuntas et al. (2016) use the ROA and the ROE as performance variables. The authors cluster German insurance groups into three groups. The first group consists of small specialized insurers, the second group of insurers with a focus on the life and health business and the third group are large diversified insurers. The authors study if the parent companies' affiliation to one of these groups affects the ROE and ROA performance of the property-liability subsidiaries. The authors find evidence for a relationship between the performance and the parent company's group allocation. The first group with a specialization strategy outperforms the two other groups. Liebenberg and Sommer (2008) find that in the US property-liability sector insurers that focus on one business line perform better in terms of ROA and ROE than insurers that diversify across several lines.

We calculate the ROE by dividing the profits from ordinary activities by the equity capital and the ROA by dividing profits by the total investments (at closing value). We use the ROE as a measure for the total insurance market and the non-life sector. The ROA serves as a life insurance specific indicator. In fact, the denominator of total investments is an important measure for the life business and matters less in non-life insurance. We define the ROE and the ROA as follows:

$$
\begin{aligned}
R O E_{i, t}^{s} & =\frac{\text { profits from ordinary activities }_{i, t}^{s}}{\text { equity capital }_{i, t}^{s}} \\
R O A_{i, t} & =\frac{\text { profits from ordinary activities }}{i, t} \\
\text { total capital investments } &
\end{aligned}
$$

Technical margin (TM). For the life insurance business, we further include the technical margin as an indicator. The technical margin, expressed in percent, is calculated as the ratio of the 
net technical result over the net technical reserves for regular and unit-linked business. This approach is taken from Lorson and Wagner (2014), who use the technical margin as a measure of profitability for the life business. The definition of the technical margin is as follows:

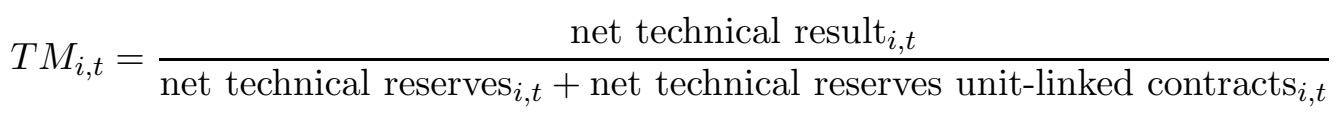

Loss ratio (LR). We include the loss ratio as a specific indicator for the non-life insurance business. It is calculated as the sum of the gross claims paid and the change in gross provisions for outstanding claims, as defined in $\S 41(1)-(2)$ RechVersV (RechVersV, 2015), divided by the GWP. The loss ratio is also used as a performance indicator by Zhang and Nielson (2013). They include the loss ratio as independent variable in their analysis on the likelihood of insolvency, arguing that the likelihood is lower for insurers with a favorable claims experience. Fier et al. (2017) also include the loss ratio as control variable as part of the underwriting performance. We define the loss rate as follows:

$$
L R_{i, t}=\frac{\text { gross claims paid }_{i, t}+\text { change in gross provisions for outstanding claims }}{i, t}
$$

\section{Safety indicators}

For safety indicators we define the standard deviation of the ROE for the total market. In addition, safety is measured by the solvency I ratio for the non-life and the equity ratio for the life sector.

Standard deviation ROE (ROED). We choose the standard deviation of the insurers' profitability, measured through ROE and consider a 4-year-rolling average. This approach follows Eling et al. (2017). We define the standard deviation in year $t$ as

$$
R O E D_{i, t}=\left[\frac{1}{t-(t-3)} \sum_{k=t-3}^{t}\left(R O E_{i, k}^{s}-\phi R O E_{i}^{s}\right)^{2}\right]^{1 / 2},
$$

where $\phi R O E_{i}^{s}$ is the 4-year-rolling average ROE.

Solvency I (SO) and equity ratio (ER). The solvency margin is a widely used measure to assess an insurance company's financial health, since it shows the excess of free assets over liabilities (OECD, 2002). For the solvency calculation in the non-life sector, we use the solvency I standard. This is available in the range of our data panel from 2001 to 2016 with solvency I standards being replaced by solvency II only as of January 2016 (European Insurance and Occupational Pension Authority, 2016). We define the solvency ratio as the equity capital divided by the solvency capital requirement. The calculation of the solvency capital requirement is based on two indexes, one on a premium basis and one on a claims basis, whereby the higher one will be used to derive the capital requirement. The premium index is calculated as follows: $18 \%$ on the first $61.3 € \mathrm{mn}$ of premiums (volume of GWP in a financial year) and $16 \%$ above $61.3 € \mathrm{mn}$ of premiums. On a claims basis, the index is $26 \%$ on the first $42.9 € \mathrm{mn}$ of claims (average claims over the last three financial years) and $23 \%$ above $42.9 € \mathrm{mn}$ of claims. Both solvency margins include a retention ratio, automatically set to be at least $50 \%$, if the calculated retention ratio should be below this threshold. The equity capital is defined as the sum 
of equity, the intangible assets, the profit participation rights and the subordinated loans. Our solvency calculations follow Nguyen (2008) and Heep-Altiner et al. (2015). Information on the premiums and claims basis is taken from OECD (2002).

$$
\begin{aligned}
S O_{i, t}= & \frac{\text { equity capital }_{i, t}^{S}}{\max \left(\text { premium index }_{i, t} ; \text { claims }_{\text {index }} i, t\right)} \\
\text { premium index }_{i, t}= & 18 \% \cdot 61.3 € \mathrm{mn} \cdot \text { retention rate } \\
& +16 \% \cdot(\text { premiums }-61.3 € \mathrm{mn})^{+} \cdot \text { retention rate } \\
\text { claims index } & \\
& 26 \% \cdot 42.9 € \mathrm{mn} \cdot \text { retention rate } \\
& +23 \% \cdot(\text { claims }-42.9 € \mathrm{mn})^{+} \cdot \text { retention rate },
\end{aligned}
$$

where $(\cdot)^{+}$stands for $\max (\cdot ; 0)$ and the retention rate has a minimum of $50 \%$.

The solvency calculation in the life insurance sector is based on the equity ratio "Eigenmittelquote" of the German Insurance Association (GDV). This ratio is regularly reported in the yearly publication on the life insurance market (GDV, 2015) and serves as a good approximation for the solvency calculation. In addition, calculating the solvency is very difficult from an external perspective because some data is not published (Heimes, 2003; von Fürstenwerth and Weiss, 2001). The equity capital is defined as the sum of equity, the free part of the reserves for premium refunds and the final surplus share funds. In line with the GDV, we define the equity ratio as the equity capital divided by the sum of $4 \%$ of the mathematical provisions plus $1 \%$ of the provisions for unit-linked contracts and $0.3 \%$ of the risk capital (Heimes, 2003; Schradin et al., 2003).

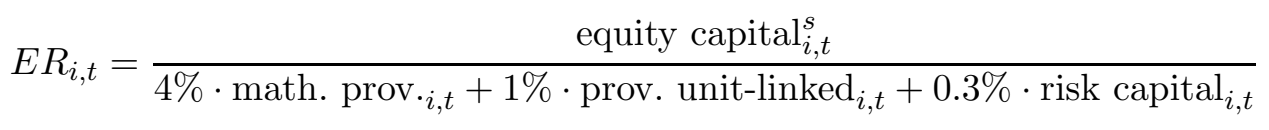

\section{Other indicators}

Our other indicators include the market share, the business sector and the legal status of the company. With the market share, we account for the relative size of the insurance business and with the business sector we distinguish the life and the non-life business from the total market. When considering the legal status as a covariate, we are in line with, e.g. Lorson and Wagner (2014). They include the legal status in their analysis on sales efficiency in life insurance and report that the indicator is also included in papers from, e.g., Cummins et al. (1999), Spiller (1972), and Berry-Stölzle et al. (2012). The legal status can take the three values listed, mutual and public, whereby all entities of a group are assigned the legal status of the mother company. This view is also taken by Nemson (2014) who structures the individual companies according to the legal form of the overall group.

Finally, we control for the financial year since many indicators are influenced by events in a certain year. For example, heavy wind- and hailstorms in one year can drive up the loss ratio in non-life and a change in the tax regulation can have an effect on the growth rates in the sales of life insurance products. Table 1 provides an overview of the indicators and their variables 
across the business lines.

\begin{tabular}{|c|c|c|c|c|c|}
\hline Objective & Indicator & Variable & Life & Non-life & Total \\
\hline \multirow[t]{3}{*}{ Growth $\mathcal{G}$} & Premium growth & $P G_{i, t}^{s}$ & $\checkmark$ & $\checkmark$ & $\checkmark$ \\
\hline & Investments growth & $I G_{i, t}$ & $\checkmark$ & & \\
\hline & Contracts growth & $C G_{i, t}$ & & $\checkmark$ & \\
\hline \multirow[t]{4}{*}{ Profitability $\mathcal{P}$} & Return on equity & $R O E_{i, t}^{s}$ & & $\checkmark$ & $\checkmark$ \\
\hline & Return on assets & $R O A_{i, t}$ & $\checkmark$ & & \\
\hline & Technical margin & $T M_{i, t}$ & $\checkmark$ & & \\
\hline & Loss ratio & $L R_{i, t}$ & & $\checkmark$ & \\
\hline \multirow[t]{3}{*}{ Safety $\mathcal{S}$} & Std. dev. ROE & $R O E D_{i, t}$ & & & $\checkmark$ \\
\hline & Equity ratio & $E R_{i, t}$ & $\checkmark$ & & \\
\hline & Solvency ratio & $S_{-} O_{i, t}$ & & $\checkmark$ & \\
\hline \multirow[t]{3}{*}{ Other } & Market share & $M S_{i, t}^{s}$ & $\checkmark$ & $\checkmark$ & $\checkmark$ \\
\hline & Sector & $S C_{i}^{s}$ & $\checkmark$ & $\checkmark$ & $\checkmark$ \\
\hline & Legal status & $L G_{i}$ & $\checkmark$ & $\checkmark$ & $\checkmark$ \\
\hline
\end{tabular}

Table 1: Overview of the key indicators in the life, non-life and total insurance business.

\section{$2.2 \quad$ Descriptive statistics}

Our panel data is based on the annual reporting of insurance companies for the years from 2001 to 2016. The data panel comprises 4808 company-years on a single entity level. The data is aggregated at group level by adding up the individual financial statements of the single entities for the life and the non-life sector, which results in 2639 group-years. The data is based on single accounts along local GAAP and does not represent consolidated financial statements. The evolution of the key indicators for growth, profitability and safety is provided in Table 2 . In the first part we show the market averages for the key indicators for the life insurance sector; in the second part we report on the non-life insurance sector. The first reported year is 2002, since this is the first year where we can calculate the growth indicators. In Figures 1 and 2 we provide a graphical illustration.

Starting the discussion with life insurance, we observe that both growth indicators, the GWP and the investment volume, increase over time. The GWP increase from $64 €$ bn to $84 € \mathrm{bn}$. The growing volume of the life insurance market is also evident in the increase of the investment volume, which starts with $582 €$ bn in 2002 and reaches $873 €$ bn in 2016. Regarding the profitability indicators, we see that the two performance indicators ROA and technical margin develop similarly. The ROA has the highest values in the time periods from 2005 to 2006 and 2010 to 2013 with values above $0.33 \%$. They reach their lowest values at the beginning of the last financial crisis (2008 and 2009) and in 2014. The ROA drops to $0.21 \%$ in 2008 and stays at $0.24 \%$ in 2009 ; in 2014 the ROA reaches $0.22 \%$. We note the same development for the technical margin. After moderate results in 2002 with $0.36 \%$, the technical margin improves, especially in the years $2005(0.55 \%)$ and $2006(0.48 \%)$. With the financial crisis, the technical margin decreases to $0.33 \%$ in 2008 and in 2009 even to $0.31 \%$. The technical margin recovers in the following three years, but never reaches a higher value than $0.41 \%$ (2010 and 2011). In 2014 the technical margin drops to $0.24 \%$ and recovers only moderately in $2015(0.33 \%)$ and in $2016(0.27 \%)$. The equity ratio starts with values above $170 \%$ before rising above $200 \%$ for the years 2006 and 2007. After that, the ratio constantly declines from $194 \%$ in 2008 to $147 \%$ in 


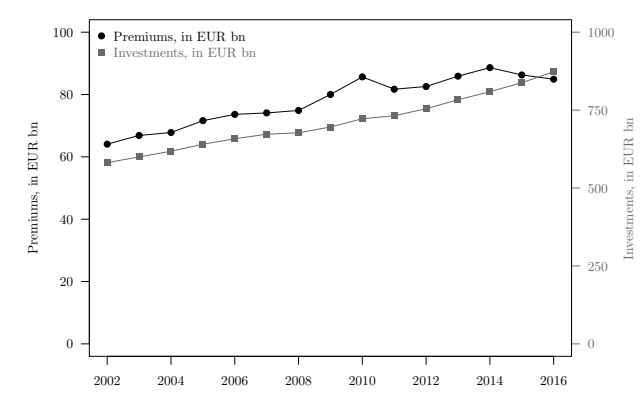

(a) Premium and investment volume.

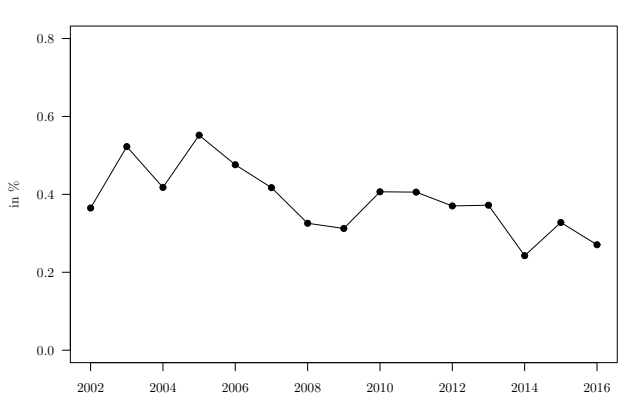

(c) Technical margin.

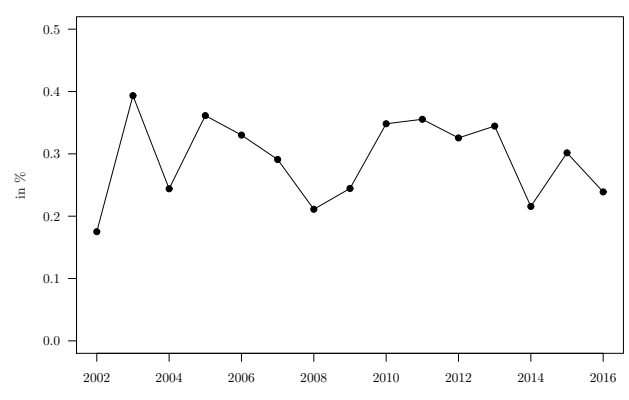

(b) ROA.

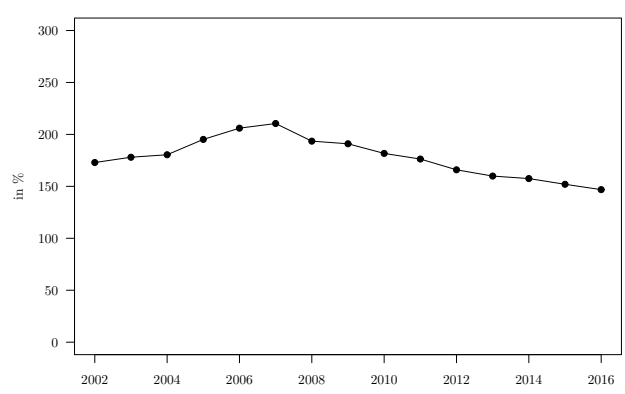

(d) Equity ratio.

Figure 1: Overview of key indicators in the life insurance market.

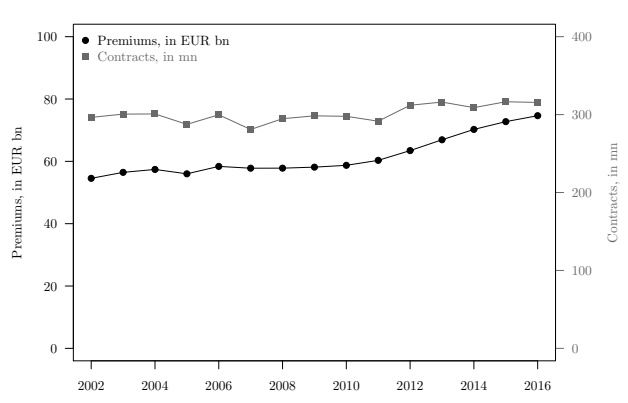

(a) Premium and contract volume.

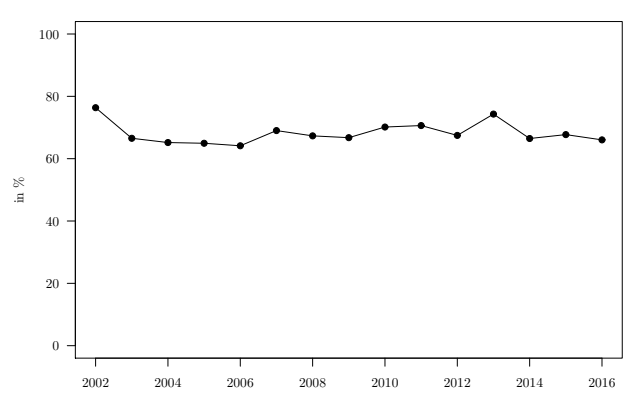

(c) Loss ratio.

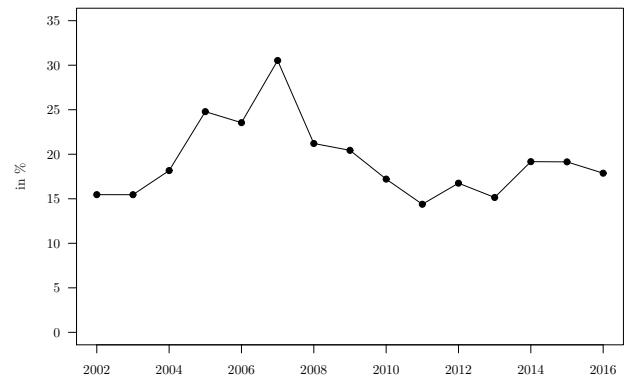

(b) ROE.

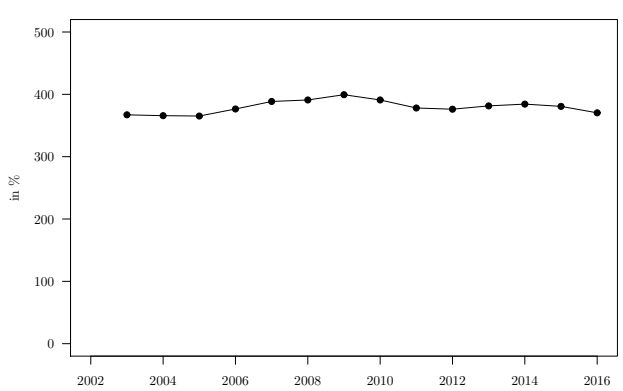

(d) Solvency I ratio.

Figure 2: Overview of key indicators in the non-life insurance market. 
2016.

For the non-life insurance market, we also observe that the two growth indicators GWP and number of contracts increase over time. The GWP grow by $34 \%$ from $54.6 €$ bn in 2002 to $74.7 €$ bn in 2016 while the number of contracts increases by $6 \%$ from $296.5 \mathrm{mn}$ to 315.6 $\mathrm{mn}$. Regarding the profitability indicators, we notice that the ROE has the highest values in the years 2005 to 2007 , moving above $20 \%$ in 2005 and above $30 \%$ in 2007 . With the start of the financial crisis, the ROE declines to $21 \%$ in 2008 and $20 \%$ in 2009 and then stays below $20 \%$ until 2016. The loss ratio is around $70 \%$ from 2002 to 2016, with the highest values in $2002(76.4 \%)$ and $2013(74.3 \%)$ and the lowest ones in $2005(64.9 \%)$ and $2006(64.1 \%)$. For the solvency I ratio, we observe an increasing average ratio from $367 \%$ in 2003 to $399 \%$ in 2009 . After 2009 the solvency I ratio decreases below 390\% and reaches 370\% in 2016.

\subsection{Panel data statistics}

In the regression models we include data starting from the year 2004, the first year in which the ROE standard deviation (4-year-rolling average) can be calculated. For the regression analysis we exclude certain data outliers for the growth, profitability and safety indicators. Thereby we exclude data points lying under the $0.5 \%$ quantile and above the $99.5 \%$ quantile. Table 3 shows the relevant statistics for the cleaned data, which is used in our modeling. It shows the $0.5 \%$ and the $99.5 \%$ quantiles $\left(q_{0.5 \%}, q_{99.5 \%}\right)$, the mean, the median, and the number of observations $N$ for all companies and for the whole time period. In addition, we provide information on the shares of the different sectors and legal types in the cleaned data panel.

\section{Empirical analysis}

\subsection{Model framework}

In order to test how the objectives growth, profitability and safety are related, we use basic single linear regression models. We define a regression model for each of the key indicators introduced in Section 2.1. We also consider the influence of the legal status $L G_{i}$ (categorical variable), the market share of the insurer $M S_{i, t}^{s}$ (linear variable) and the sector $S C_{i}^{s}$ (binary variable, only in the total market regressions) as separate variables. Further, the effects of the financial year are controlled for (but coefficients are not reported). The growth objective is measured through $G \in \mathcal{G}=\left\{P G^{s}, I G, C G\right\}$, the profitability by $P \in \mathcal{P}=\left\{R O E^{s}, R O A, T M, L R\right\}$ and the safety by $S \in \mathcal{S}=\left\{R O E D^{s}, E R, S O\right\}$. In each regression we alternatively choose one of the indicators in $\mathcal{G}, \mathcal{P}$ and $\mathcal{S}$. In the below regressions, $\beta_{0}$ is the intercept, $\gamma_{i}$ stands for the fixed effects of the calendar years and $\epsilon_{i, t}$ is the error term.

We consider the following general regression models for growth,

$$
\begin{aligned}
& G_{i, t}^{s}=\beta_{0}+\beta_{P} P_{i, t}^{s}+\beta_{L G} L G_{i}+\beta_{M S} M S_{i, t}^{s}+\beta_{S C} S C_{i}^{s}+\gamma_{i}+\epsilon_{i, t}, \\
& G_{i, t}^{s}=\beta_{0}+\beta_{S} S_{i, t}^{s}+\beta_{L G} L G_{i}+\beta_{M S} M S_{i, t}^{s}+\beta_{S C} S C_{i}^{s}+\gamma_{i}+\epsilon_{i, t},
\end{aligned}
$$

for profitability,

$$
\begin{gathered}
P_{i, t}^{s}=\beta_{0}+\beta_{G} G_{i, t}^{s}+\beta_{L G} L G_{i}+\beta_{M S} M S_{i, t}^{s}+\beta_{S C} S C_{i}^{s}+\gamma_{i}+\epsilon_{i, t}, \\
P_{i, t}^{s}=\beta_{0}+\beta_{S} S_{i, t}^{s}+\beta_{L G} L G_{i}+\beta_{M S} M S_{i, t}^{s}+\beta_{S C} S C_{i}^{s}+\gamma_{i}+\epsilon_{i, t},
\end{gathered}
$$




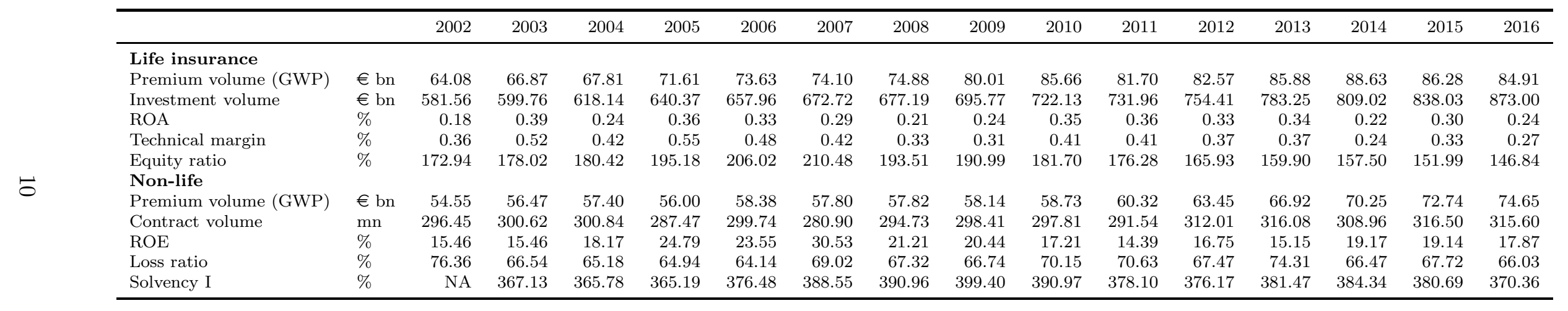

Table 2: Overview of the growth, profitability and safety key indicators in the German life and non-life insurance market from 2002 to 2016. 


\begin{tabular}{|c|c|c|c|c|c|c|}
\hline Objective & Variable & $q_{0.5 \%}$ & $q_{99.5 \%}$ & Mean & Median & $N$ \\
\hline \multirow[t]{5}{*}{ Growth $\mathcal{G}$} & $P G^{\text {total }}$ & -13.70 & 34.25 & 3.59 & 2.51 & 2028 \\
\hline & $P G^{\text {life }}$ & -13.13 & 22.91 & 2.18 & 1.41 & 657 \\
\hline & $P G^{\text {non-life }}$ & -15.25 & 38.85 & 4.33 & 2.96 & 1369 \\
\hline & $I G$ & -2.48 & 15.84 & 3.56 & 2.97 & 657 \\
\hline & $C G$ & -11.18 & 41.56 & 3.11 & 1.33 & 1298 \\
\hline \multirow[t]{5}{*}{ Profitability $\mathcal{P}$} & $R O E^{\text {total }}$ & -14.94 & 47.11 & 13.17 & 11.40 & 2043 \\
\hline & $R O E^{\text {non-life }}$ & -21.10 & 51.26 & 13.08 & 11.14 & 1384 \\
\hline & $R O A$ & -0.06 & 1.18 & 0.27 & 0.23 & 657 \\
\hline & $T M$ & 0.03 & 1.03 & 0.39 & 0.36 & 657 \\
\hline & $L R$ & 18.86 & 106.57 & 63.19 & 64.21 & 1384 \\
\hline \multirow{3}{*}{ Safety $\mathcal{S}$} & $R O E D$ & 0.75 & 29.28 & 07.22 & 05.54 & 2003 \\
\hline & $E R$ & 109.55 & 304.37 & 175.49 & 165.45 & 657 \\
\hline & $S_{-}$ & _ 97.29 & 1523.04 & 341.53 & 272.41 & 1324 \\
\hline \multirow[t]{13}{*}{ Other } & Market share $M S$ & & & & & \\
\hline & Life & 0.01 & 18.86 & 1.88 & 0.81 & 693 \\
\hline & Non-life & 0.00 & 14.81 & 0.98 & 0.11 & 1458 \\
\hline & Sector $S C$ & & & Share & & \\
\hline & Life & & & 32.22 & & 693 \\
\hline & Non-life (baseline) & & & 67.78 & & 1458 \\
\hline & Legal status $L G$ & & & Share & & \\
\hline & Listed life (baseline) & & & 35.21 & & 244 \\
\hline & Mutual ${ }^{\text {life }}$ & & & 49.78 & & 354 \\
\hline & Public life & & & 15.01 & & 104 \\
\hline & Listed $^{\text {non-life }}$ (baseline) & & & 34.98 & & 510 \\
\hline & Mutual ${ }^{\text {non-life }}$ & & & 51.65 & & 753 \\
\hline & Public ${ }^{\text {non-life }}$ & & & 13.37 & & 195 \\
\hline
\end{tabular}

Table 3: Statistics of the panel data used for the analysis (all figures are expressed in \%).

and for safety,

$$
\begin{aligned}
S_{i, t}^{s} & =\beta_{0}+\beta_{G} G_{i, t}^{s}+\beta_{L G} L G_{i}+\beta_{M S} M S_{i, t}^{s}+\beta_{S C} S C_{i}^{s}+\gamma_{i}+\epsilon_{i, t} . \\
S_{i, t}^{s} & =\beta_{0}+\beta_{P} P_{i, t}^{s}+\beta_{L G} L G_{i}+\beta_{M S} M S_{i, t}^{s}+\beta_{S C} S C_{i}^{s}+\gamma_{i}+\epsilon_{i, t} .
\end{aligned}
$$

We start with a regression model for the total insurance sector $(s=$ total $)$, using indicators that are valid for both sectors, while controlling for the influence of the sectors $S C_{i}^{s}$. The results are presented in Table 4. Then, we run separate regression analyses for the life (Table 5) and the non-life sectors (Table 6).

\subsection{Results}

\subsubsection{Total insurance sector modeling}

Table 4 presents the results of the regression analysis for the total insurance business in three parts, beginning with the regressions on growth (R1, R2), followed by the regressions on profitability (R3, R4) and finally the regressions on safety (R5, R6). The column LHS (left-handside) refers to the dependent variable considered. The column labeled $\beta$ relates to the linear 
variable indicated under RHS (right-hand-side). For better readability, we only report the sign of the respective $\beta$ coefficients, their significance as well as the adjusted $R^{2}$ value for the model. When applying (R1) to (R6) on the total market three variables are available: $P G^{\text {total }}, R O E^{\text {total }}$ and $R O E D . \beta_{L G 2}$ and $\beta_{L G 3}$ are the coefficients of mutual and public companies respectively, when compared to the baseline listed firms; $\beta_{M S}$ is the coefficient of the variable market share; $\beta_{S C}^{\text {life }}$ compares the life sector to the non-life baseline.

Starting with growth, we find that a higher profitability in terms of ROE goes along with higher premium growth. Regarding the size of the business, our results suggest that larger insurance groups, in terms of market share, tend to grow slower than smaller groups. The results for our sector variable show that life insurance companies ceteris paribus relate to lower growth rates than non-life insurers. The safety variable $R O E D$ as well as the legal form are not significant in any of the models (R1) and (R2). In the regressions on profitability we find that higher growth rates and lower safety levels (in terms of higher standard deviation of the ROE) relate to higher profitability in terms of ROE. Further, both mutual and public insurers go along with lower profitability when compared to listed companies. Regarding the size of the business, larger companies relate to higher profitability than smaller companies and life insurers are found to be less profitable than non-life insurers. Our regressions on safety show that higher profitability comes with a lower safety level (ROE standard deviation increases with ROE). Regarding the legal form, mutual and public insurers relate to higher safety levels than listed companies, while larger insurers go along with a lower safety level. The growth variable and the sector variable are not significant.

\begin{tabular}{|c|c|c|c|c|c|c|c|c|}
\hline & LHS & RHS & $\beta$ & $\beta_{L G 2}$ & $\beta_{L G 3}$ & $\beta_{M S}$ & $\beta_{S C}^{\text {life }}$ & $R^{2}$ \\
\hline $\begin{array}{l}\text { (R1) } \\
(\mathrm{R} 2)\end{array}$ & $\begin{array}{l}\text { Regressi } \\
P G^{\text {total }} \\
P G^{\text {total }}\end{array}$ & $\begin{array}{l}\text { n on grov } \\
R O E^{\text {total }} \\
R O E D\end{array}$ & $\begin{array}{l}\mathbf{h} \\
+* \\
+\end{array}$ & $\begin{array}{l}+ \\
+\end{array}$ & - & $\begin{array}{l}-* \\
-\end{array}$ & $\begin{array}{l}-* * * \\
-* * *\end{array}$ & $\begin{array}{l}0.02 \\
0.02\end{array}$ \\
\hline $\begin{array}{l}\text { (R3) } \\
\text { (R4) }\end{array}$ & $\begin{array}{l}\text { Regressi } \\
R O E^{\text {total }} \\
R O E^{\text {total }}\end{array}$ & $\begin{array}{l}\text { n on prof } \\
P G^{\text {total }} \\
R O E D\end{array}$ & $\begin{array}{l}\text { ability } \\
+{ }^{*} \\
+* * *\end{array}$ & $\begin{array}{l}-* * * \\
-* * *\end{array}$ & $\begin{array}{l}-* * * \\
-* *\end{array}$ & $\begin{array}{l}+* * * \\
+* * *\end{array}$ & $\begin{array}{l}-* * \\
-* *\end{array}$ & $\begin{array}{l}0.12 \\
0.14\end{array}$ \\
\hline $\begin{array}{l}(\mathrm{R} 5) \\
(\mathrm{R} 6)\end{array}$ & $\begin{array}{l}\text { Regressi } \\
R O E D \\
R O E D\end{array}$ & $\begin{array}{l}\text { n on safe } \\
P G^{\text {total }} \\
R O E^{\text {total }}\end{array}$ & $\begin{array}{l}+ \\
+* * *\end{array}$ & $\begin{array}{l}-* * * \\
-* * *\end{array}$ & $\begin{array}{l}-* * * \\
-* * *\end{array}$ & $\begin{array}{l}+* * * \\
+\end{array}$ & - & $\begin{array}{l}0.08 \\
0.10\end{array}$ \\
\hline
\end{tabular}

Significance codes: ${ }^{* * *} p<0.001,{ }^{* *} p<0.01,{ }^{*} p<.05, . p<0.1$; year fixed effects; $N=1834$.

Table 4: Results of the regression models applied on the total insurance sector.

\subsubsection{Separate life and non-life modeling results}

Table 5 presents the results of the regression analysis for the life insurance business. The table is again structured in three parts and reports the results on growth, profitability and safety. The growth and profitability parts contain two indicators on the left-hand-side (LHS) of the regression: premium $P G^{\text {life }}$ and investment growth $I G$ for the regressions on growth and the $R O A$ and the technical margin $T M$ for the regressions on profitability. For the regression on safety we have the equity ratio $E R$ as only indicator. Starting with growth, we find that a higher profitability in terms of ROA goes along with higher premium and investment growth rates, while the technical margin is only significant for the growth in capital investments. A higher safety level in terms of a higher equity ratio relates to a higher growth of premiums and 
investments. Mutual and public insurers relate to higher premium and investment growth rates than listed companies. Larger insurance groups go along with higher premium growth. For the regressions on profitability we find a positive and significant relationship between both growth variables, premium and investment growth, and the ROA as well as a positive and significant relation between investment growth and the technical margin. The equity ratio does not have a significant effect. Regarding the legal form, we find that mutual and public insurers relate to a lower profitability than listed companies, especially for the ROA. The regressions on safety show that a higher growth of premiums and investments go along with a higher safety level in terms of a higher equity ratio. Further, mutual and public insurers relate to a higher equity ratio than listed insurers. A higher market share goes along with a higher equity ratio, which indicates a higher safety level.

\begin{tabular}{|c|c|c|c|c|c|c|c|c|c|c|c|c|c|c|}
\hline & LHS & RHS & $\beta$ & $\beta_{L G 2}$ & $\beta_{L G 3}$ & $\beta_{M S}$ & $R^{2}$ & LHS & RHS & $\beta$ & $\beta_{L G 2}$ & $\beta_{L G 3}$ & $\beta_{M S}$ & $R^{2}$ \\
\hline & \multicolumn{14}{|c|}{ Regression on growth } \\
\hline$(\mathrm{R} 1)$ & $P G^{\text {life }}$ & $R O A$ & $+* *$ & $+* * *$ & $+* * *$ & $+^{*}$ & 0.13 & $I G$ & $R O A$ & $+* * *$ & $+* * *$ & $+* * *$ & + & 0.13 \\
\hline (R1) & $"$ & $T M$ & + & $+* * *$ & $+* * *$ & $+*$ & 0.12 & $"$ & $T M$ & $+*$ & $+* *$ & $+* * *$ & + & 0.07 \\
\hline \multirow[t]{2}{*}{ (R2) } & $"$ & $E R$ & $+*$ & $+* *$ & $+* * *$ & + & 0.13 & $"$ & $E R$ & $+* *$ & + & $+* * *$ & - & 0.07 \\
\hline & \multicolumn{14}{|c|}{ Regression on profitability } \\
\hline (R3) & $R O A$ & $P G^{\text {life }}$ & $+* *$ & $-* * *$ & $-* * *$ & + & 0.12 & $T M$ & $P G$ & + & $-{ }^{*}$ & - & - & 0.07 \\
\hline (R3) & $"$ & $I G$ & $+* * *$ & $-* * *$ & $-* * *$ & + & 0.17 & $"$ & $I G$ & $+*$ & $-{ }^{*}$ & - & - & 0.08 \\
\hline \multirow[t]{2}{*}{ (R4) } & $"$ & $E R$ & + & $-* * *$ & $-* * *$ & + & 0.11 & $"$ & $E R$ & - & - & - & - & 0.07 \\
\hline & \multicolumn{14}{|c|}{ Regression on safety } \\
\hline (R5) & $E R$ & $P G^{\text {life }}$ & $+^{*}$ & $+* * *$ & + & $+* *$ & 0.13 & & & & & & & \\
\hline (R5) & , & $I G$ & $+* *$ & $+* * *$ & + & $+* * *$ & 0.13 & & & & & & & \\
\hline (R6) & $"$ & $R O A$ & + & $+* * *$ & $+*$ & $+* * *$ & 0.13 & & & & & & & \\
\hline (R6) & $"$ & $T M$ & - & $+* * *$ & $+*$ & $+* * *$ & 0.12 & & & & & & & \\
\hline
\end{tabular}

Table 5: Results of the regression models applied on the life insurance sector.

Table 6 presents the results of the regression analysis for the non-life insurance business. The growth and profitability parts contain two indicators on the LHS: premium $P G^{\text {non-life }}$ and contract growth $C G$ for the regressions on growth and the $R O E^{\text {non-life }}$ and the loss ratio $L R$ for the regressions on profitability. For the regression on safety we have the solvency ratio $S O$ as only indicator. Starting with growth, we find that a higher loss ratio goes along with lower premium and contract growth. Further, a higher safety level in terms of a higher solvency ratio is related to a lower growth of premiums and contracts. Regarding the legal form, the coefficient on the legal status $L G$ variable is only significant for public insurers, which relate to lower premium and contract growth rates. In addition, we find a negative and significant relationship between the size of the business and the growth rates. For the regressions on profitability we observe that higher premium and contract growth relates to a lower loss ratio while we have no significant results for ROE. Further, we find a negative and significant relation between the solvency ratio and the ROE. Regarding the legal form, mutual and public insurers relate to a lower profitability level in terms of ROE and public insurers also in terms of the loss ratio. Thus, we conclude that mutual and public insurers relate to lower profitability levels than listed insurers. The regressions on safety show that higher premium and contract growth relates to lower solvency and thus safety levels. In addition, higher profitability relates to lower safety levels. The results along the legal form show that mutual and public insurers go along with higher solvency ratios than listed companies and that the relation between the market share and the solvency ratio is positive and significant. 


\begin{tabular}{|c|c|c|c|c|c|c|c|c|c|c|c|c|c|c|}
\hline & LHS & RHS & $\beta$ & $\beta_{L G 2}$ & $\beta_{L G 3}$ & $\beta_{M S}$ & $R^{2}$ & LHS & RHS & $\beta$ & $\beta_{L G 2}$ & $\beta_{L G 3}$ & $\beta_{M S}$ & $R^{2}$ \\
\hline & \multicolumn{14}{|c|}{ Regression on growth } \\
\hline (R1) & $P G^{\text {non-life }}$ & $R O E^{\text {non-life }}$ & - & - & $-* *$ & $-* * *$ & 0.03 & $C G$ & $R O E^{\text {non-life }}$ & - & - & $-* *$ & $-* * *$ & 0.02 \\
\hline (R1) & $"$ & $L R$ & $-* * *$ & - & $-{ }^{*}$ & $-* * *$ & 0.04 & $"$ & $L R$ & $-{ }^{*}$ & - & $-*$ & $-{ }^{* * *}$ & 0.02 \\
\hline \multirow[t]{2}{*}{ (R2) } & $"$ & SO & $-{ }^{*}$ & - & $-{ }^{*}$ & $-{ }^{* * *}$ & 0.03 & $"$ & $S O$ & $-{ }^{*}$ & - & - & $-{ }^{* * *}$ & 0.02 \\
\hline & \multicolumn{14}{|c|}{ Regression on profitability } \\
\hline (R3) & $R O E^{\text {non-life }}$ & $P G^{\text {non-life }}$ & - & $-^{* * *}$ & $-{ }^{* * *}$ & $+^{* * *}$ & 0.10 & $L R$ & $P G^{\text {non-life }}$ & $-* * *$ & + & $+^{* * *}$ & $t^{* * *}$ & 0.07 \\
\hline (R3) & $"$ & $C G$ & - & $-* * *$ & $-{ }^{* * *}$ & $+^{* * *}$ & 0.10 & $"$ & $C G$ & $-{ }^{*}$ & + & $+^{* * *}$ & $t^{* * *}$ & 0.06 \\
\hline \multirow[t]{2}{*}{ (R4) } & $"$ & SO & $-* * *$ & $-*$ & $-* *$ & $+* * *$ & 0.12 & $"$ & $S O$ & - & + & $+* * *$ & $+* * *$ & 0.06 \\
\hline & \multicolumn{14}{|c|}{ Regression on safety } \\
\hline (R5) & SO & $P G^{\text {non-life }}$ & $-{ }^{*}$ & $+* * *$ & $+* * *$ & $+* * *$ & 0.11 & & & & & & & \\
\hline (R5) & $"$ & $C G$ & $-{ }^{*}$ & $+* * *$ & $+{ }^{* * *}$ & $+* * *$ & 0.11 & & & & & & & \\
\hline (R6) & $"$ & $R O E^{\text {non-life }}$ & $-* * *$ & $+^{* * *}$ & $+^{* * *}$ & $+^{* * *}$ & 0.12 & & & & & & & \\
\hline (R6) & $"$ & $L R$ & - & $+^{* * *}$ & $+^{* * *}$ & $+* * *$ & 0.11 & & & & & & & \\
\hline
\end{tabular}

Table 6: Results of the regression models applied on the non-life insurance sector.

\section{Concluding remarks}

As reported in the summary of the regression results in Table 7, the regressions for the total insurance market yield results that follow usual expectations. We find a positive and significant relationship between growth and profitability and a negative and significant relation between safety levels and profitability. Further, mutual and public insurers relate to a lower profitability but higher safety levels than listed companies. Large companies tend to grow at a lower rate but are more profitable. The only surprising result for the total market is that larger companies relate to a lower safety level. For the structure of our analysis it is relevant that the sector variable is significant. This is why we highlight the similarities and differences between the sectors by conducting separate regression analyses.

For both sectors, we observe a positive and significant relation between growth and profitability. In addition, mutual and public insurers go along with a lower profitability and a higher safety level when compared to listed companies. Interestingly, larger companies from both sectors are related to higher safety levels than smaller companies. This result is different than the finding for the total insurance market. It can be explained by the different indicators used to measure the safety levels. The equity ratio for life and the solvency I ratio for non-life insurance are more specific to each sector than the standard deviation of the ROE used for the total market.

The sectors differ as follows: While higher growth relates to a higher safety level in life it goes along with a lower safety level in non-life. For the life insurance sector, this can be explained by the effect of new business. A strong new business development, especially for products with low or no interest rate guarantees, helps life companies to decrease their average interest rate guarantees in the in-force business and thus has a positive influence. For nonlife, further analysis is necessary to determine which line of business, e.g. motor insurance, is responsible for this effect. In fact, to some extent, important amounts of additional capital reserves may be required and need to be built up in case of important non-life growth. With regard to further research, an inclusion of the business lines in the analysis could help to derive interesting recommendations for the management and to detail the impact of the business lines on the strategic objectives. 


\begin{tabular}{|c|c|c|c|c|}
\hline & Insurers with ... & growth & profitability & safety \\
\hline \multirow{7}{*}{$\begin{array}{l}\vec{\pi} \\
\overrightarrow{0} \\
\overrightarrow{0}\end{array}$} & ... a higher growth & & higher & n.s. \\
\hline & ... a higher profitability & higher & & lower \\
\hline & ... a higher safety level & n.s. & lower & \\
\hline & ...the legal form mutual & n.s. & lower & higher \\
\hline & ...the legal form public & n.s. & lower & higher \\
\hline & ... a higher market share & lower & higher & lower \\
\hline & ...the sector life & lower & lower & n.s. \\
\hline \multirow{6}{*}{$\stackrel{\mathscr{H}}{\hookrightarrow}$} & ... a higher growth & & higher & higher \\
\hline & ... a higher profitability & higher & & n.s. \\
\hline & ... a higher safety level & higher & n.s. & \\
\hline & ...the legal form mutual & higher & lower & higher \\
\hline & ...the legal form public & higher & lower & higher \\
\hline & ... a higher market share & higher & higher & higher \\
\hline \multirow{6}{*}{$\begin{array}{l}\mathscr{0} \\
: 1 \\
\vdots \\
0 \\
z\end{array}$} & ... a higher growth & & higher & lower \\
\hline & ... a higher profitability & higher & & lower \\
\hline & ... a higher safety level & lower & lower & \\
\hline & ...the legal form mutual & n.s. & lower & higher \\
\hline & ...the legal form public & lower & lower & higher \\
\hline & ... a higher market share & lower & not clear & higher \\
\hline
\end{tabular}

Bold text for significance levels ${ }^{* * *} p<0.001$ and ${ }^{* *} p<0.01$;

Normal text for significance levels $* p<.05$ and $. p<0.1$;

Italic text when results for the life and non-life sector are different;

n.s. stands for not significant.

Table 7: Summary of the regression results.

\section{References}

Altuntas, M., J. Rauch, and S. Wende, 2016, Strategic Group Performance and Dynamics under Different Economic Conditions, The Geneva Papers on Risk and Insurance - Issues and Practice, 41(2):325-347.

BaFin, 2015, Statistik der BaFin - Erstversicherungsunternehmen und Pensionsfonds 2014.

Berry-Stölzle, T. R., A. P. Liebenberg, J. S. Ruhland, and D. W. Sommer, 2012, Determinants of Corporate Diversification: Evidence From the Property-Liability Insurance Industry, Journal of Risk and Insurance, 79(2):381-413.

Cole, C. R., S. G. Fier, J. M. Carson, and D. Andrews, 2015, The Impact of Insurer Name Changes on The Demand for Insurance, Journal of Risk and Insurance, 82(1):173-204.

Cummins, J. D., M. A. Weiss, and H. Zi, 1999, Organizational Form and Efficiency: An Analysis of Stock and Mutual Property-Liability Insurers, Management Science, 45(9):1254-1269.

De Haan, L. and J. Kakes, 2011, Momentum or Contrarian Investment Strategies: Evidence from Dutch Institutional Investors, Journal of Banking and Finance, 35(9):2245-2251.

Demary, D. M. and J. Matthes, 2014, Das aktuelle Niedrigzinsumfeld: Ursachen, Wirkungen und Auswege. 
Eling, M. and M. Luhnen, 2008, Understanding Price Competition in the German Motor Insurance Market, Zeitschrift für die gesamte Versicherungswissenschaft, 97(1):37-50.

Eling, M., J. Ruo, and P. Schaper, 2017, Get the Balance Right: A Simultaneous Equation Model to Analyze Growth, Profitability, and Safety, University of St. Gallen, School of Finance Research Paper, 2017(16).

European Insurance and Occupational Pension Authority, 2016, Solvency II - Going Live.

Fier, S. G., A. P. Liebenberg, and I. A. Liebenberg, 2017, Insurer Growth Strategies, Risk Management and Insurance Review, 20(3):309-337.

Gal, J., H. Gründl, and M. I. Dong, 2016, The Evolution of Insurer Portfolio Investment Strategies for Long-term Investing, OECD Journal: Financial Market Trends, 2016(1):1-55.

GDV, 2014, 5 Fakten zum Höchstrechnungszins.

GDV, 2015, Die deutsche Lebensversicherung in Zahlen.

GDV, 2016, Absenkung des Höchstrechnungszinses erfolgt zu kurzfristig.

Heep-Altiner, M., R. Drahs, J. Möller, and M. Weber, 2015, Finanzierung im (Schaden)Versicherungsunternehmen: Schritt für Schritt zu den Finanzierungsanforderungen eines (Schaden-) Versicherungsunternehmens. Verlag Versicherungswirtschaft GmbH, Karlsruhe.

Heimes, K., 2003, Jahresabschlußanalyse von Versicherungsunternehmen: Gewinn, Wachstum und Sicherheit von Erstversicherungsunternehmen nach HGB. Josef Eul Verlag Lohmar.

Liebenberg, A. and D. Sommer, 2008, Effects of Corporate Diversification: Evidence From the Property Liability Insurance Industry, Journal of Risk and Insurance, 75(4):893-919.

Lorson, J. and J. Wagner, 2014, Sales Efficiency in Life Insurance: The Drivers for Growth in the German Market, Geneva Papers on Risk and Insurance - Issues and Practice, 39(3):493-524.

Maichel-Guggemoos, L. and J. Wagner, 2018, Profitability and Growth in Motor Insurance Business: Empirical Evidence from Germany, The Geneva Papers on Risk and Insurance Issues and Practice, 43(1):126-157.

Maichel-Guggemoos, L. and J. Wagner, 2019, Life insurance asset allocation and investment returns - Empirical evidence from Germany, University of Lausanne, Working Paper.

Nemson, J., 2014, Geschäftsmodell VVaG: Rahmenbedingungen, Herausforderungen und Chancen. Verlag Versicherungswirtschaft GmbH, Karlsruhe.

Nguyen, T., 2008, Rechnungslegung von Versicherungsunternehmen. Verlag Versicherungswirtschaft GmbH, Karlsruhe.

OECD, 2002, Insurance Solvency Supervision.

RechVersV, 2015, Verordnung über die Rechnungslegung von Versicherungsunternehmen.

Schradin, V. H. R., S. Gronenberg, M. Kreeb, B. Reichenbach, and O. Willmes, 2003, Lebensversicherung: Beim Sicherheitskapital ist die Decke sehr dünn geworden, Versicherungswirtschaft, 58(18):1407-1412. 
Schwarz, G., U. Stephan, R. V. Hoensbroech, and M. Gribat, 2008, European Growth Champions in Insurance, The Boston Consulting Group.

Spiller, R., 1972, Ownership and Performance: Stock and Mutual Life Insurance Companies, Journal of Risk and Insurance, 39(1):17-25.

Swiss Re Institute, 1998, World Insurance in 1996: Modest Growth in the Insurance Industry, Sigma, 1998(4).

Swiss Re Institute, 2007, World Insurance in 2006: Premiums Came Back to Life, Sigma, 2007(4).

Swiss Re Institute, 2015, World Insurance in 2014: Back to Life, Sigma, 2015(4).

Swiss Re Institute, 2017, World Insurance in 2016: The China Growth Engine Steams Ahead, Sigma, 2017(3).

von Fürstenwerth, J. and A. Weiss, 2001, VersicherungsAlphabet (VA): Begriffserläuterungen der Versicherung aus Theorie und Praxis. Verlag Versicherungswirtschaft GmbH, Karlsruhe.

Zhang, L. and N. Nielson, 2013, Solvency Analysis and Prediction in Property-Casualty Insurance: Incorporating Economic and Market Predictors, Journal of Risk and Insurance, 82(1):97-124. 


\section{Appendix}

\begin{tabular}{|c|c|}
\hline 1811 Hagelgilde & LKH \\
\hline $\mathrm{ADAC}$ & LSH \\
\hline AEGIDIUS & LV 1871 \\
\hline AGCS & LVM \\
\hline Agrorisk & Mapfre \\
\hline ALH & Mecklenburgische \\
\hline Allcura & Medien \\
\hline Allianz & Mercedes \\
\hline Ammerländer & Minerva \\
\hline ARAG & MSIG \\
\hline Athora & Münchener Verein \\
\hline Augur & Neue Rechtsschutz \\
\hline AXA & Neuendorfer \\
\hline Badische Gemeinde & Nürnberger \\
\hline Baloise & NV Hagel \\
\hline Barmenia & $\mathrm{OKV}$ \\
\hline Bayerische Hausbesitzer & öRAG \\
\hline BBB & $\ddot{\mathrm{oSA}}$ \\
\hline BBV & Ostangler \\
\hline Bergische & Ostbeverner \\
\hline Concordia & Ostfriesische LBK \\
\hline Continentale & öV Braunschweig \\
\hline DARAG & Provinzial NordWest \\
\hline Debeka & Provinzial Rheinland \\
\hline Delvag & $\mathrm{R}+\mathrm{V}$ \\
\hline DEVK & RheinLand \\
\hline DFV & Roland \\
\hline DMB & RS Reise-Schutz \\
\hline Docura & S.-H. des Bäckerhandwerks \\
\hline Dolleruper & Schleswiger \\
\hline East-West Assekuranz & Schutzverein Deutscher Rheder \\
\hline ERGO & Schwestern Versicherung \\
\hline Euro Aviation & SDK \\
\hline Extremus & Signal Iduna \\
\hline F. Laeisz & SOVAG \\
\hline Fahrlehrer & Stuttgarter \\
\hline Föhr, Amrum und Halligen Gebäudeversicherungsgilde & SV Sachsen \\
\hline Frankfurter Leben & SV Sparkassen \\
\hline Gartenbau BG & Swiss Life \\
\hline Generali & Talanx \\
\hline GGG & Thüga \\
\hline GHV & Uelzener \\
\hline Gothaer & Uniqa \\
\hline Grundeigentümer & UniVersa \\
\hline GVO & Vereinigte Schiffs-Versicherung \\
\hline GVV & VGH \\
\hline Haftpflichtkasse Darmstadt & VHV \\
\hline Häger & VKB \\
\hline Hanse Marine & Volkswohl Bund \\
\hline HanseMerkur & VPV \\
\hline HDI Global & VRK \\
\hline HDNA & VV dt. Eisenbahnen \\
\hline Heidelberger Leben & VW FINANCIAL SERVICES \\
\hline Helvetia & $\mathrm{W}+\mathrm{W}$ \\
\hline Hübener & Waldenburger \\
\hline HUK & Wertgarantie \\
\hline IDEAL Versicherung & WGV \\
\hline INTER & Wiener Städtische \\
\hline Isselhorster & Würzburger \\
\hline Itzehoher & WWK \\
\hline KS Auxilia & Zurich \\
\hline LBN & \\
\hline
\end{tabular}

Table 8: List of insurance groups included in the panel data. 